\title{
The first record of Corbicula fluminea (O. F. Müller, 1774) in Moravia (SE Czech Republic)
}

\author{
Petr KomzÁK ${ }^{1}$, Luboš Beran ${ }^{2} \&$ Michal HorsáK ${ }^{3}$ \\ ${ }^{1}$ Morava River Board, s.e., Dřevařská 11, CZ-602 00 Brno, Czech Republic, e-mail: komzak@pmo.cz \\ ${ }^{2}$ Nature Conservation Agency of the Czech Republic, Regional Office Kokořinsko - Máchưv kraj Protected Landscape Area \\ Administration, Česká 149, CZ-27601 Mělník, Czech Republic, e-mail: lubos.beran@nature.cz \\ ${ }^{3}$ Department of Botany and Zoology, Masaryk University, Kotlářská 2, CZ-611 37 Brno, Czech Republic, email: horsak@sci.muni.cz
}

Komzák P., Beran L. \& Horsák M., 2018: The first record of Corbicula fluminea (O. F. Müller, 1774) in Moravia (SE Czech Republic). - Malacologica Bohemoslovaca, 17: 28-30. Online serial at $<$ http://mollusca.sav.sk $>$ 13-Nov-2018.

Corbicula fluminea, an invasive bivalve of SE Asian origin, has been recorded in the Morava River in Moravia (SE Czech Republic, Danube River basin) for the first time in 2018.

Key words: Corbicula fluminea, Moravia, Czech Republic, invasive species, bivalve

\section{Introduction}

Corbicula fluminea (O. F. Müller, 1774) is a small freshwater clam of the family Corbiculidae, native in SE China, Korea, SE Russia, and the Ussuri Basin (MorTon 1986, WOODWARD \& QUINN 2011). It has light-coloured shell, ornamented by distinct, concentric sulcations (growth ridges) and reaching a length of about $5 \mathrm{~cm}$. It was introduced to North America, for the first time recorded in the Columbia River in Washington in 1924 (empty shells) and 1938 (live specimens) (Counts 1981, 1986). Originally it was thought to enter the United States as a food item used by Chinese immigrants (HANNA 1966), but there is no direct evidence of that. As an alternative scenario, it may have come in with the importation of the Giant Pacific oyster Magallana gigas also from the Asia. As its ontogenesis includes also planktonic larvae, which can be released to waste water of transatlantic ships, this is believed to be the way how the species was introduced from the USA to Europe (KINZELBACH 1991). The first record from Europe was conducted near the western borders of Portugal and France in 1980 (Mouthon 1981). Soon after that it has colonised Austria, Bulgaria, France, Germany, Luxembourg, the Netherlands, Poland, Portugal, Spain, Switzerland and the United Kingdom (Araujo et al. 1993).

\section{Results and discussion}

Corbicula fluminea was in the Czech Republic recorded for the first time in the Elbe River in 1999 as the result of an upstream dispersal from Germany (BERAN 2000). Now it has colonized a long stretch of the Elbe River and lower sections of its main Czech tributaries as the Vltava and Ohře Rivers (Fig. 1). In the Elbe River floodplain it is also known from some sandpits isolated from the main channel (L. BERAN pers. obs.). The first record from the Slovak Danube River was reported by ŠTEFFEK et al. (2002). The spreading appears to be very quick as now the species is commonly distributed across the whole stretch of the Slovak Danube River and lowland part of the Elbe River (Horsák et al. 2018). It was likely that it will soon or later spread upstream also to the Morava River (the Danube River left tributary) and will reach the Czech Republic also from the east. This was even more probable once reported in large densities across the whole Austrian section of the Morava River (FISCHER \& REISCHÜTZ 2018). Thus, it was only matter of time when it will reach also the Czech part. It has happened right now and $C$. fluminea has been for the first time encountered in the Morava River (48 $\left.41^{\prime} 16.5^{\prime \prime} \mathrm{N}, 16^{\circ} 59^{\prime} 26.4^{\prime \prime} \mathrm{E}\right)$ near the town of Lanžhot in the SE Czech Republic (Fig. 2). The first record of three live clams was conducted on June $18^{\text {th }} 2018$ by the first author of this paper during a routine annual monitoring by using a semi-quantitative 3-minute kick sampling with a hand net according to the PERLA system (KOKEŠ et al. 2006). Subsequently on September $17^{\text {th }} 2018$, he sampled at the site qualitatively, mainly on the stone riprap, and found 33 individuals (Fig. 3). As the species has not been recorded during his sampling at the site in previous years, we can preciously date the arrival of $C$. fluminea.

This clam was found to be one of the most invasive freshwater mollusc species with an enormously high capacity of passive dispersal and colonization of new environment. In non-native ecosystems it was found to reach extremely high density of its populations, covering the river beds by a thick layer of individuals and mainly empty shells. Such situations were reported from many North American rivers, where maximum densities of $C$. fluminea can range from 10,000 to 20,000 inds $/ \mathrm{m}^{2}$, often dominating the benthic community (SICKEL 1986). The highest known density of 131,000 inds $/ \mathrm{m}^{2}$ was documented in California (BRITTON \& MORTON 1982). In the Czech Republic the highest densities were found in an artificial channel near the Elbe 


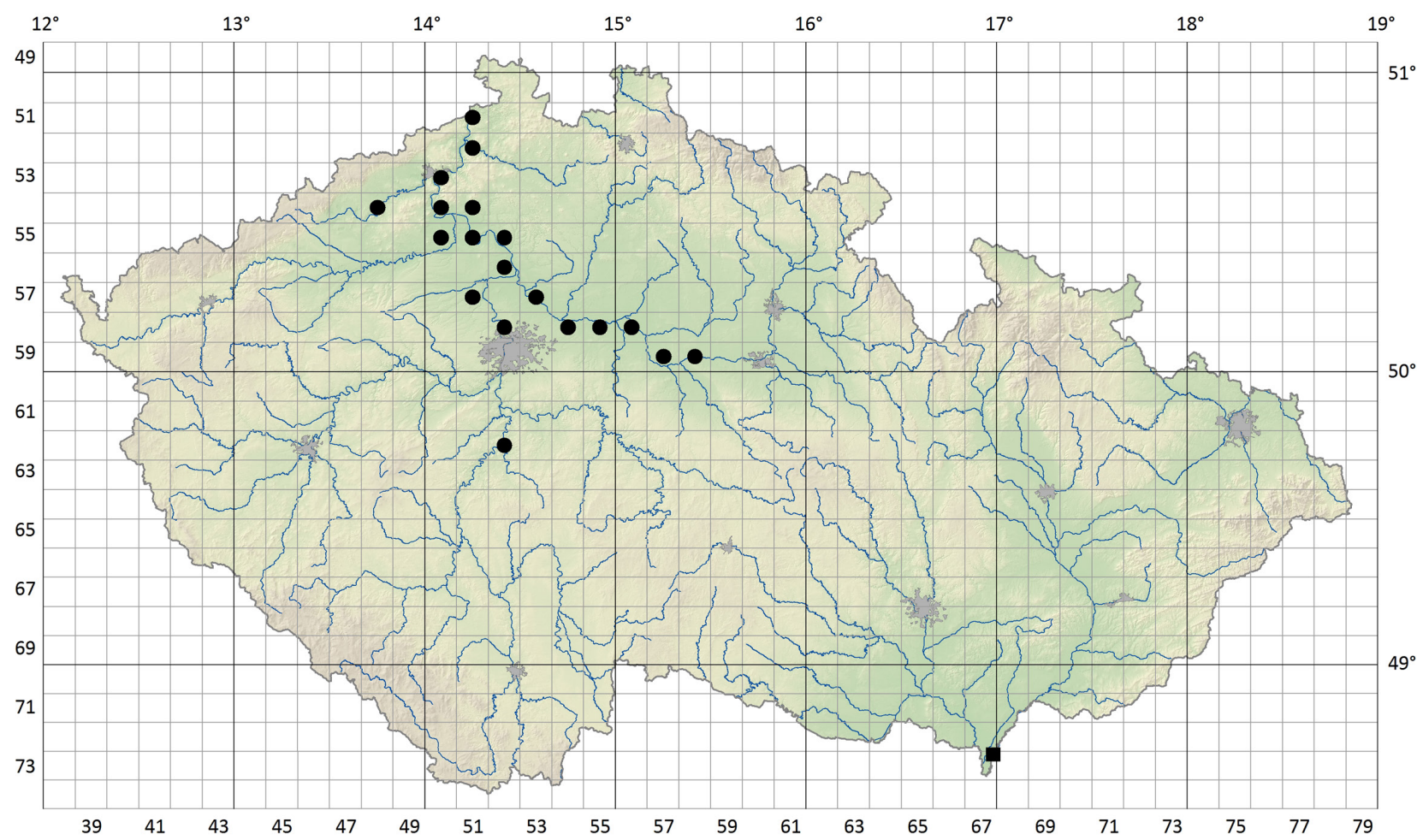

Fig. 1. Current distribution of Corbicula fluminea in the mapping grid cells in the Czech Republic (prepared by J. Vrba on the bases of the second author's data and database of Nature Conservation Agency of the Czech Republic). New record in the Morava River is marked by a square. Data source: (C) COSMC 2016, C NCA CR 2018.

River, where varying between $1045-4224$ inds $/ \mathrm{m}^{2}$ (BERAN 2013). Also in the Slovak part of the Danube River the numbers of empty shells on the river shore suggest rather high densities (M. Horsák pers. obs.). The species has enormous capacity of a high population growth as it can self-fertilize, releasing up to 2,000 juveniles per day and more than 100,000 in lifetime. In favourable conditions it can quickly become a dominant species, as was already observed at some Czech sites (L. BERAN pers. obs.), with harm consequences for the native species and ecosystem functioning.

\section{Acknowledgements}

We thank Jan Vrba for preparing the map.

\section{References}

Araujo R., Moreno D. \& Ramos M. A., 1993: The Asiatic clam Corbicula fluminea (Müller, 1774) (Bivalvia: Corbiculidae) in Europe. - Americal Malacological Bulletin, 10: 39-49.

BERAN L., 2000: First record of Corbicula fluminea (Mollusca: Bivalvia) in the Czech Republic. - Acta Societatis Zoologicae Bohemicae, 64: 1-2.

BERAN L., 2013: Současný stav invaze a neobvyklá lokalita korbikuly asijské [The current state of the invasion and the unusual habitat of the Asian clam]. - Živa, 1: 25. (in Czech)

Britton J. C. \& Morton B., 1982: A dissection guide, field and laboratory manual for the introduced bivalve Corbicula fluminea. - Malacologia Review, Supplement, 3: 1-82.

Counts C. L., 1981: Corbicula fluminea (Bivalvia: Sphaeriacea) in British Columbia. - The Nautilus, 95: 12-13.

CounTs C. L., 1986: The zoogeography and history of the invasion of the United States by Corbicula fluminea (Bivalvia: Corbiculidae). - American Malacological Bulletin, Special Edition, 2: 7-39.
FisCher W. \& ReISchütz A., 2018: Beiträge zur Kenntnis der österreichischen Molluskenfauna LIX. Zur Ausbreitung von Corbicula fluminea (O. F. MÜLLER 1774) im östlichen Weinviertel (Niederösterreich). - Nachrichtenblatt der Ersten Vorarlberger Malakologischen Gesellschaft, 25: 13-14.

HanNa G. D., 1966: Introduced mollusks of western North America. - California Academy of Sciences Occasional Papers, 48: 1-108.

Horsák M., Čejka T., JuŘičKová L., Beran L., HoráčKová J., HlaváČ J. Č., DvořÁK L., HájeK O., Diví̌́̌̌e J., MaŇas M. \& LožEK V., 2018: Check-list and distribution maps of the molluscs of the Czech and Slovak Republics. - Online at http:// mollusca.sav.sk/malacology/checklist.htm, checklist updated at July 10, 2018, maps updated at August 5, 2018.

KinZELBACH R., 1991: Die Körbchenmuscheln Corbicula fluminalis, Corbicula fluminea und Corbicula fluviatilis in Europa (Bivalvia: Corbiculidae). - Meinzer Naturwissenschaftliches Archiv, 29: 215-228.

KoKeš J., ZahrádKová S., NĚMeJCová D., HodovskÝ J., JaRKovskÝ J. \& Soldán T., 2006: The PERLA System in the Czech Republic: A multivariate approach for assessing the ecological status of running waters. - Hydrobiologia, 566: 343-354.

Morton B., 1986: Corbicula in Asia - an updated synthesis. American Malacological Bulletin, Special Edition, 2: 113-124. Mouthon J., 1981: Sur la présence en France et au Portugal de Corbicula (Bivalve: Corbiculidae) originaire d'Asie. - Basteria, 45: 109-116.

SiCKEL J. B., 1986: Corbicula population mortalities: factors influencing population control. - American Malacological Bulletin, Special Edition, 2: 89-94.

ŠTEFFEK J., ČEJKA T. \& NAGEL K., 2002: The distribution of Corbicula fluminea in the Slovakian part of the river Danube. - Soosiana, 23(30): 72-73.

WOODWARD S. L. \& QUINN J. A., 2011: Encyclopedia of invasive species: from Africanized honey bees to zebra mussels (Vol. 1). - California: ABC-CLIO, LLC, 764 pp. 


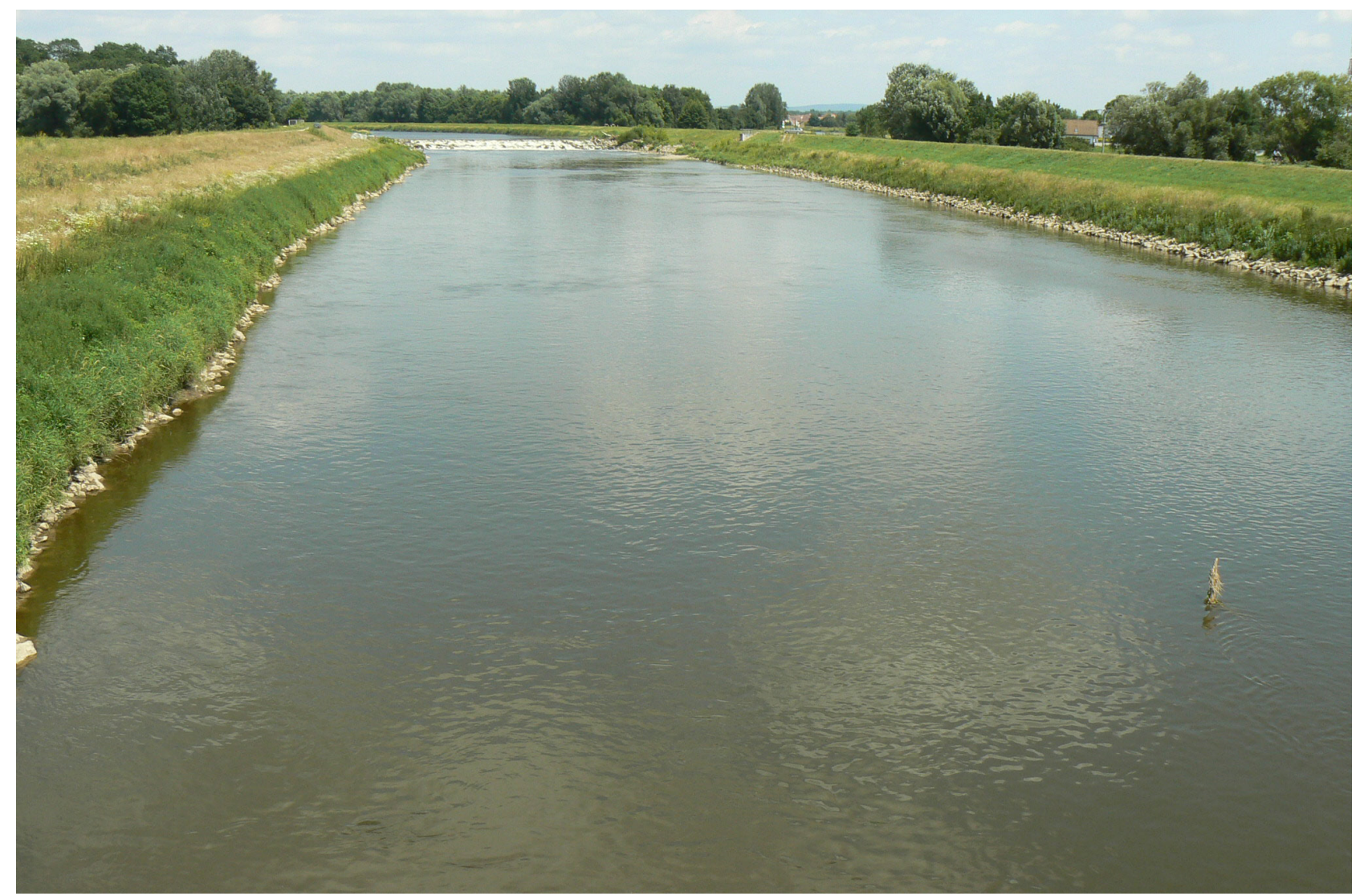

Fig. 2. Site of the first record of Corbicula fluminea in the Morava River. Photo by P. Komzák.

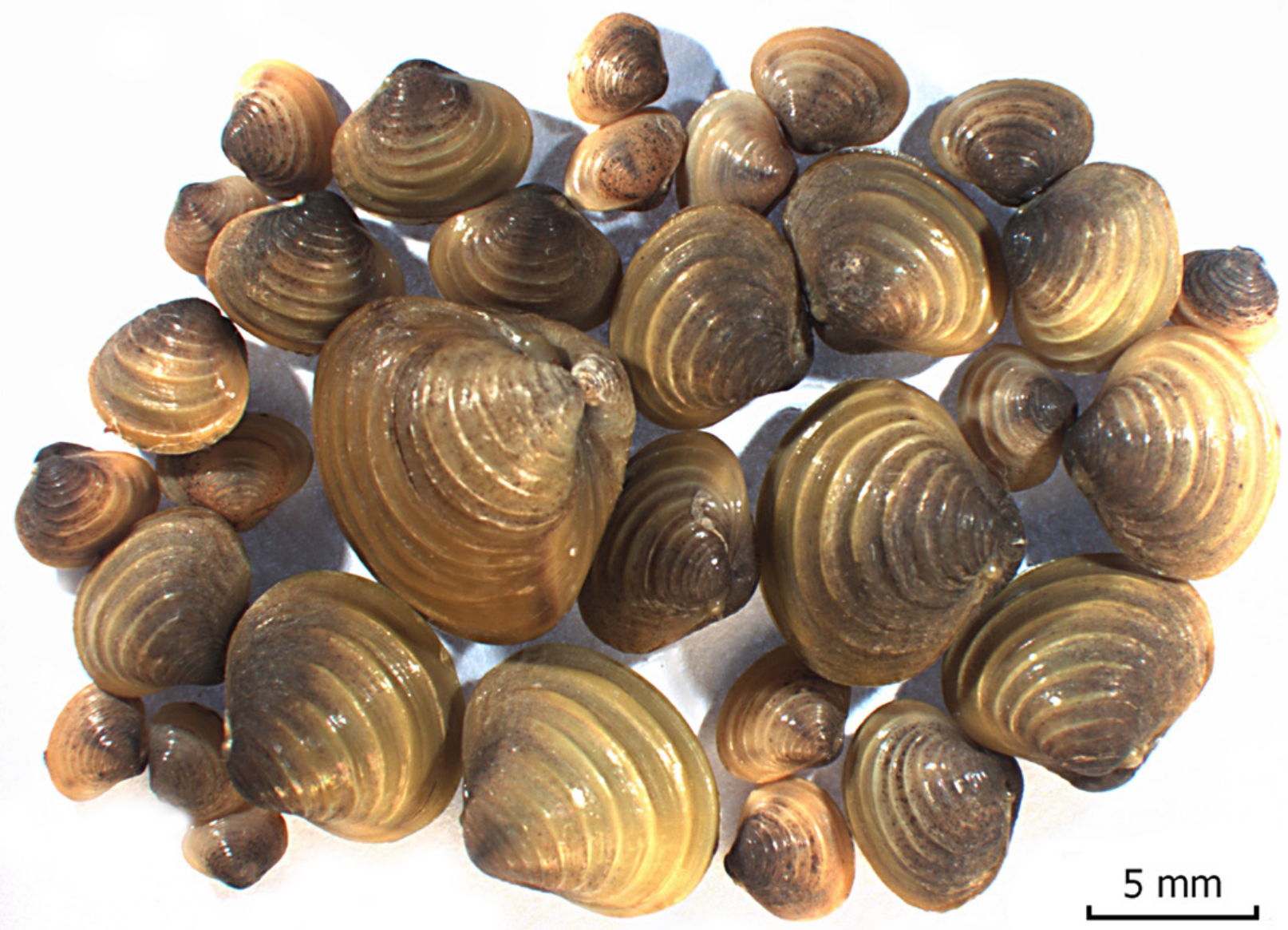

Fig. 3. Shells of the recorded individuals of Corbicula fluminea. Photo by P. Komzák. 